\title{
PERIODIZATION OF ART AND INDUSTRIAL EDUCATION DEVELOPMENT IN UKRAINE
}

\author{
Alla Dyachenko \\ Ph.D., Associate Professor at the Department of Industrial Design and Computer Technology, \\ Mykhailo Boichuk Kyiv State Academy of Decorative Applied Arts and Design, Ukraine \\ e-mail: diachenko.alla@ya.ru, orcid.org/0000-0003-4496-5931
}

\section{Summary}

The essence of the term "art-industrial education" is highlighted in the article. The main stages of the development of art - industrial education in Ukraine are singled out. The peculiarities of the formation of art-industrial education at each stage are revealed. It is emphasized that due to the expansion of the centers of the functioning of artistic and craft industrial schools, the artistic style began to go beyond the limits of the one national at the third stage.It is noted that at the present stage of development, the existing system of special art education is looking for new ways to satisfy the demand for specialists in art- and- industrial and design education. The purpose of the article is to analyze the development of art-industrial education in Ukraine. New realities of the country demanded a great number of specialists in the field of applied arts education. Artists, who were capable of independent creative design, industrial painters, who were able to understand the tasks and organize work on their implementation in manufacturing, craftsmen who were aware of the methods of making art products, as well as artisans who had technical drawing skills and were ready to work with increasingly complex technical equipment, were in demand at plants and factories.

Keywords: development, artist, educational institution, art-industrial school, design.

DOI: https://doi.org/10.23856/4506

\section{Introduction}

Nowadays, when our country is going through times of change, authentic historical knowledge, which is the only link that unites pedagogical experience of previous generations and attempts to build a modern and effective system of public education, is becoming extremely significant. The importance of art and industrial education and its development, determination of prospects have become really important in Ukraine. Therefore, great relevance is given to the analysis of the experience of forming the national system of special art education, which was evolving over several centuries under the conditions of multinational Ukrainian state, being under the influence of world experience, aimed at solving, primarily, practical tasks which were put forward by the demands of social progress. An in-depth analysis of activities and functioning, are crucial today.

The problems of the development of art and industrial education in Ukraine are highlighted in the works of such scientists as (L. Voloshyna, 2008), (Y. Zvenyhorodska, 2011), (D. Kozubovskyi, 2010), (G. Maksysko,1971), (L. Sokoliuk 2004), (R. Shmahalo, 2006). A retrospective of art and industrial education was identified by the following scientists: (V. Nemtsova, 2004), (S. Mihal,2017), (I. Kodlubai,2016), (O. Pobirchenko,2013), (L. Synyshyn,2014), (Z. Tkanko,2019).

Researches by (V. Hlazychev, 2015), (V. Tiahura, 2013), (A. Khmelovskyi, 2003), (A. Chebykin, 2020), (S. Shabelnyk,2017), (M. Yakovlev,2009) are comparing historical and 
modern experience of domestic and foreign design education. Scientist ( $V$. Danylenko, 2010) comprehensively characterized the model of Ukrainian design, where he was able to reveal its national and globalization aspects. (S. Verhunov, 2006) devoted his scientific research to the analysis of three-dimensional modeling in industrial design of Ukraine at the end of XX- beginning of XXI century.

\section{The first stage (XVIII-middle of XIX century)}

The development of art-industrial education in Ukraine occured in accordance with social, political and economic circumstances of that time. Completion of the industrial revolution, development of transport infrastructure, expansion of internal and external trade, a rapid population contributed to the strong rise of culture and education in the country. Progress in education development, great public interest in art and culture had a stimulating effect on the economic and social recovery in Ukraine. Within conditions of modernization of Ukraine's economy, culture, education, it was impossible to meet the demand for highly qualified personnel by practical training or with efforts of separate educational institutions. The need for artists and draftsmen for the industry was so acute that finally led to the formation of such an independent professional field of vocational education as art-industrial one (Shabelnyk, 2012).

So, art and industrial education has the same beginning as purely artistic one, but what is most significant it is learning to paint that is recognized as necessary for the development of taste and training for various kinds of artistic work in all branches of industry (Encyclopedic Dictionary, 1903:7).

The establishment of art and industrial education in Ukraine, its social foundations give reason to distinguish four stages in contexts of commonly-European related tendencies (Shmahalo, 2001:21):

The first stage (XVIII-middle of XIX century.) - centres of folk art creativity are becoming the basis of founding the first educational institutions. So, classes of painting, drawing and architecture were founded in Kharkiv (1767) In 1844, there was opened "Technical Academy", which became the beginning of design education in Lviv (Shmahalo, 1999:28).

An important centre of art and industrial education was a private drawing school, founded in 1869 on the initiative of Maria Dmitrovna Raievska - Ivanova. The school in the 60's of the XIX century became one of the first links in the chain of art- and industry-related educational institutions after Strohanov College in Moscow and Shtyhlyts specialized school in St. Petersburg (Sokoliuk, 1984 : 8). Art school of M.D. Raievska - Ivanova was publicly accessible, children from poor families studied there for free.

So, the school provided initial training for many future artists and contributed to the spread of art education in masses. Free training unfavorably affected the material possessions of the school, which at the time had no government subsidies. Thanks to the experience gained abroad M. D. Raievska - Ivanova opened evening classes of technical drawing at her school, where artisans received knowledge at their spare time that made it possible to improve their crafts and make them more profitable. The educational process of the Raievska-Ivanova school is largely determined by the contingent of students and the need of the city for art staff of a specific specialty. The following types of students are characteristic of the school: 1) future artisans, 2) students who sought to enter the academy of arts, 3) students who learnt to draw in order to enter technical higher education institutions, 4) amateurs who turned into art lovers (Sokoliuk, 1986:80). Such a diverse group of students required that the school should be a source of artistic education in a broad sense. The main subject taught at school was drawing from nature. It was regarded as the basis of the visual art for artists of all specialities. Except 
for the picture, which was the main subject, they studied drawing, mastered painting, learnt the history of arts, were engaged in sculpting, using natural sketches of flowers and plants, made samples of stylized ornament, which, as a result, were widely used in architectural and decorative plasticity of art Nouveau (Zvenyhorodska, 2011:14).

At the peak of its activities, the school got a big shock - it was supposed to be closed because of M. Raievska-Ivanova's illness at the end of 1894. Only in September the following year the school was restored in a new status, entirely at the expense of the city, which led to the loss of art and industrial inclination, there was a gradual process of requalification for training artists of easel painting (Nemtsova, 2004: 102).

\section{The second stage (the end of XII - the beginning of XX century)}

The second stage (the end of XII - the beginning of XX century), which includes the following sub-stages:

1. 1877 is the beginning of a systematic activity for the elevation of national arts and crafts, the orientation of professional schools to the creative direction of mastering crafts.

2. 1878-1884 years - directing the activities of the established industrial schools at preserving and developing traditional home crafts.

3. 1885-1902 - reorientation of tasks and goals of industrial instruction to the creation of factory industry. Under the conditions of industry development in the Southern Russia (which included Ukraine), there appeared a need to create a scientific and education centre for maintaining a new production base (Danylenko, 1988 :14). At the same time art and industrial education was created, the fundamentals of which were formed by two educational institutions: Kharkiv Institute of Technology and Drawing School of Maria Dmitrivna Rayievska-Ivanova. These institutions were the first in Ukraine in terms of their design orientation (Danylenko, 1996:10).

Kharkiv Institute of Technology (nowadays National Technical University "Kharkiv Polytechnic Institute") began its work in 1885. It was the only educational institution in the country where the teachers accepted the problems of aesthetics of technical objects most seriously, thus laying the basis for the development of engineering design of the region. The first director of the institute was V. Kyrpychov, his scientific interest was concerned with the field of theoretical mechanics, mechanical engineering in particular. He urged future engineers to consider aesthetics of the shape of the machine when designing. Alongside a talented engineer V. Kyrpychov, Y. Stoliarov,the professor of applied mechanics, was working, who understood the beauty of technology and noted that a true designer, regardless of specialty, was an artist. At the beginning of the twentieth century, teachers at the Kharkiv Institute of Technology paid much attention to engineers' art training. Therefore, drawing class was introduced to the first year students of mechanical engineering speciality, the curriculum of which involved sketching from nature with pencil, and architectural forms of antiquity and the Renaissance served as models. Also, the architecture, architectural and technical drawings were taught in the first and second years. In the third year, the course "Architectural design" was introduced, where each student on the ground of theoretical knowledge and practical skills, had to complete the project of two stone houses (Danylenko, 1988: 15). As a result, future engineers received an education that contained elements of design training (Zvenyhorodska, 2011:14).

At the beginning of XX century free academy of arts was founded in Lviv, where the common thing for all the teachers was the desire for the versatility of artistic expression in various forms of art such as architecture, graphics, design, painting, sculpture, applied art, which was the result of the struggle of progressive teachers against the conservative system of educational process and following academic rules in art (Synyshyn, 2014: 145). 
The search and experience of establishing art and industrial education of the late XIX the early XX centuries shows that all the hard work in this area finally took the form of a unified system, which was to bring the art and craft movement, art and design to a notch. The formation of art-industrial education revealed a wide range of problems that rose before the education system and were recognized by the society. But by their nature, they fell into two groups: structural- organizational problems, which required attention on the part of society and state support as well as art and aesthetic ones, which had a greater tendency to develop theoretical foundations of art education based on the history of arts and crafts theory. Structural-organizational development of art-industrial education put forward a number of specific requirements, which are shown in Fig.1 (Danylenko, 2006); (Turchyn, 2004).

Simultaneously with the educational process, art- industrial education had to solve new tasks (Tiahur, 2013:20).

- correlation of art origin and manufacture work;

- to form the theoretical basis of the criteria for the artistic and aesthetic value of industrial products;

- to find the ways of interaction of traditional folk aesthetics and modern industrial technical one.

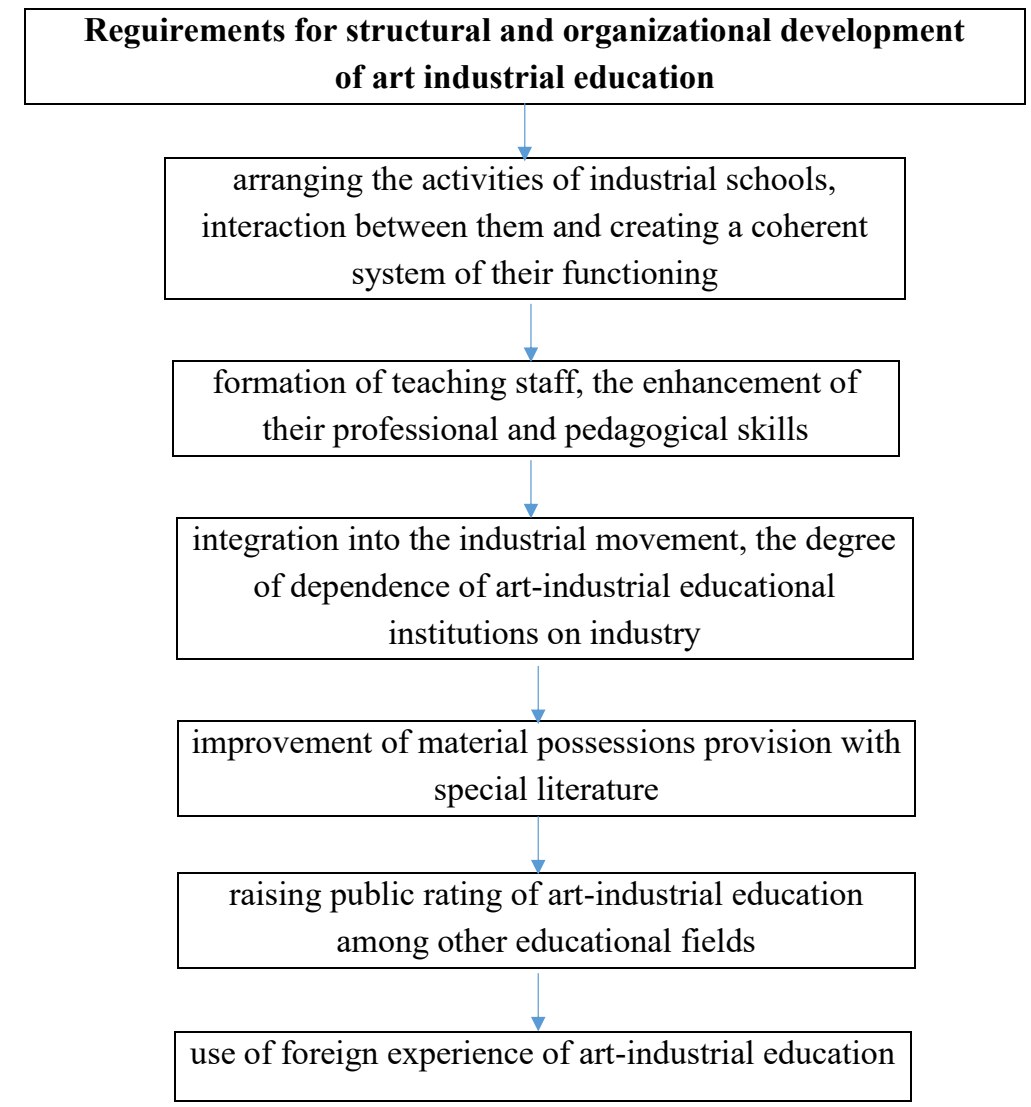

Tab. 1. Reguirements for structural and organizational development of art industrial education 
4. 1902-1910 - raising the activity of art-industrial schools, enhancing their authority and social status; growth of creative and organizational directions; number of schools and theirs structural diversity in this period reached the highest rates (Shmahalo, 2005:47).

5. 1910-1920 - related to the opening of architecture institute in Kyiv in 1918. Art-industrial institutions also existed in Odesa and Kharkiv. It can be concluded that in Ukraine by the beginning of XX century the infrastructure of art-industial education had already been developed. In the 20's, a network of state secondary art educational institutions-vocational schools was founded and developed (in Kyiv, Kharkiv, Odesa, Dnipropetrovsk, Luhansk) as well as secondary art -industrial education (Mirhorod and Mezhyhyrsk art and ceramic technical schools, art -industrial schools in Kamianets-Podilskyi, Uman, Hlynsk, Opishnia, educational and production workshops in Krolevets, Dikhtyari, Reshetylivka and other places) (Kara-Vasylieva, 2006).

\section{The third stage (1930-1990's of XX century):}

1. 1930-1950. By the end of the 1930's, the foundations for activities of art and design higher educational institutions had been laid. The important events were, for example," A retrospective exhibition of Ukrainian art for the last 30 years" (1935) and "The exhibition of products of Ukrainian crafts" (1936) at People's house. Taking into consideration all the contradictions of the exhibition expositions, they testified about artists' orientation to preserve national identity and uniqueness of both folk and professional art, as well as searches for the independent way of development in the context of involvement in contemporary tendencies of the European cultural process (Kara-Vasylieva, 2006).

In 1938 the State Institute of Plastic Arts with 5-years' study was founded in Lviv. The main feature of the educational institution was that all the process of study was devided into two periods - two-year general preparatory department at public school of plastic arts and a three-year special one. At general department students acquired art and technical knowledge combined with practical studios in workshops. The special department embraced departments of decorative painting, decorative sculpture, ceramics, textiles, graphics and advertising as well as varnishing. These departments were meant to prepare students for independent creative work by mastering the technical side of the profession chosen. Former students of the institute noted a remarkable place of such historically tested forms of studios as plein air painting, drawing, study of folk art in the educational process (Verhunov, 2010 :12).

Co-educational art-industrial school for hutsul industry was originated in Kosiv. The school comprised the following departments : carpentry and carvings, carpet-making and embroidery as well as weaving (Noha, 2009: 35). Considerable support for the development of industrial education was provided by contribution communities such as weaving community (Kosiv), " Hutsul Art "union, "Native school" community, "Dostava" Lviv community. At the initiative of these communities art and craft schools were opened and local craftsmen's exhibits were on display at various exhibitions, especially in Lviv, which was the cultural capital of the region (Shmahalo, 2006: 172). Due to the expansion of functioning of the centres of art and craft- industrial schools, the art style, developed at the territory of Halychyna, went beyond the boundaries of the folk one. This style was the basis of Ukrainian art of that time. It was spread in the European cultural space. This can be confirmed by the fact that in the art-industrial school of Vienna Ukrainian-style art projects with elements of applied art were put into life. Within time, the folk art style that had developed in Halychyna, gained recognition alongside European ones (Synyshyn, 2014: 148). 
2. 1960's - were characterized by the introduction of art-industrial education in a new phase of its development. Neither domestic experience nor foreign one had not been studied by that time. Special design bureaus implemented their first projects, the scientific institutes started systematically conducting researches. Special departments were set up at factories, research institutes and ministries. The problem of the preparation of the qualified specialists could be solved only under the condition of immediate creation of vocational training. Only in the course of professional art education, means and methods of learning developed by the efforts of the individual design practitioners, as well as techniques and methods for the formation of artistic abilities and skills were consolidated and made common asset (Shabelnyk, 2012).

3. 1970-1980's There was clear awareness of the specifics of professional art, reconsidering of folk traditions. A significant feature of this period was a widespread application of works of art industry for public buildings decoration, a cooperation with architects at the stage of design and searches for the artistic image of the building with a national identity. The period was quite fruitful in the field of the searches for individual features of professional artists and the development of art industry. The porcelain and faience plants, art glass and ceramic enterprises, new powerful textile industrial complexes started working. Professional artists, graduates of Lviv Institute of applied and decorative arts, Kyiv specialised school of applied arts, schools of decorative arts were employed at these enterprises. In 1971 we have a number of art and production associations with an extensive subsidiary system in the centres of folk art, with a system of home-work and organized product supply and sale: T. Shevchenko association, L. Ukrainka Lviv association, Zh.Liaburb Odesa association, Kharkiv association "Ukraine", "Vinnychanka","Poltavchanka", Kosiv association "Hutsulshchyna". This process was facilitated by the decree of 1975 on art crafts and the 80's were noticeable for the rapid development of these crafts. Graduates of art-and- industrial educational institutions simultaneously with the mass production created highly artistic works of art taking into account national traditions (Kara-Vasylieva, 2006).

4. 1990's - art-industrial education of this decade was remarkable for its extreme breadth and kaleidoscopy. A change of molding principles occured: the principles of utility retreated and a kind of "diffusion" of decorative and fine arts was created that gave rise to spatial art where traditional materials such as glass, wood, clay, threads were used as means of molding. Artistic education of the 90's was a multifaceted phenomenon which was developing alongside all-European and world's art process, where the category of the beautiful remained defining. Artists were finding new ways and means of embodying the aesthetic-emotional expressiveness with the help of innovative shaping, specifics of visual interaction with the environment using the latest technology and materials (Kara-Vasylieva, 2006).

\section{The fourth stage (the end of XX -the beginning of XXI century)}

The modern period the history of Ukraine is characterized by a market structure of economy,activation of foreign economic relations, entry into the system of fierce competition in production and services. (Verhunov, 2010: 15). In these circumstances, not only utility, but also aesthetic quality was of great relevance as well as product design as a reason for consumer success. In modern conditions the existing system of specialized art education was looking for the new ways to meet the demand for art and design specialists (Pobirchenko, 2013:137). 


\section{Conclusions}

So, art- industrial education was a natural result of socio-economic development of Ukraine. Since the middle of the eighteenth century the isolated educational establishments for the preparation of draftsmen for factories and manufactories had started to appear. Consequently, it led to the formation of a network of institutions of art- industrial education of the late nineteenth - the early twentieth centuries. Thanks to the extension of the functioning of art and craft-industrial schools the artistic style at the third stage began to go beyond the folk one. In the 60 's only in the course of professional art-industrial education, the means and methods of training developed by the efforts of individual design practitioners, as well as techniques and ways of forming artistic skills were consolidated and made common asset. In the 1970's-1980's graduates of art-industrial educational institutions simultaneously with the mass production created highly artistic works of art based on national traditions. Art-industrial education of the 90's was determined as a multifaceted phenomenon that was developing alongside all-European and world's art process, where the category of the beautiful remained defining. As a result, the following steps in the development of art-industrial education of Ukraine can be singled out: the first stage (XVIII -the middle of XIX century); the second stage (the end of XIX -the beginning of XX century); the third stage (1930's-1990's); the fourth stage (the end of XX - the beginning of XXI century). So, the experience of the previous centuries has shown the importance of artindustrial education in the 21 st century. The development of industrial education in Ukraine at the present stage are prospects for further research.

\section{References}

Verhunov. S. (2010). Tryvymirne modeliuvannia v promyslovomu dyzaini Ukrainy kintsia XXpochatku XXI stolittia [Three-dimensional modeling in industrial design of Ukraine of the late XX-the beginning of the XXI century]. Synopsis of thesis of Doctor of art studies. H. P. 20. (in Ukrainian)

Danylenko. V. (2006) Dyzain Ukrainy u svitovomu konteksti khudozhno-dyzainerskoi kultury KhKh stolittia (natsionalnyi ta hlobalnyi aspekty) [Ukraine's design in the world context of art-and-design culture of the twentieth century (national and global aspects)]. The dissertation of ... Doctor of art studies. P. 397. (in Ukrainian)

Danylenko. V. (1996) Korinnia kharkivskoi shkoly dyzainu [The roots of Kharkiv school of design] abstracts: All-Ukrainian scientific and methodological conference "Formation, development and modern problems of higher art and art-industrial education in Ukraine". H., HHPI. pp. 9-11. (in Ukrainian)

Danylenko. V. (1988) Vstanovlennia tradytsii inzhenernoho proektuvannia [Establishing engineering design traditions]. Technical aesthetics. № 12. pp. 14-16. (in Ukrainian)

Zvenyhorodska. Y.V. (2011) Tradytsii khudozhno-vyrobnychoi osvity u Kharkovi [Traditions of art-industrial education in Kharkiv]. HDADM Bulletin. № 8. pp. 13-17. (in Ukrainian)

Kara-Vasylieva. T. (2006) Novi pidkhody do istorii ukrainskoho mystetstva XX stolittia [New approaches to the history of Ukrainian art of XX Century] (electronic resource). Regime access: file://C:/Users/WishMasterOk/Downloads/Mist2006.3.20(1).pdf. (in Ukrainian)

Nemtsova. V. (2004) Obrazotvorche mystetstvo Kharkivshchyny [Fine arts of Kharkiv] region: Monograph.Kh.: Region-inform. P. 144. (in Ukrainian) 
Noha. O. (2009) Ivan Levynskyi : arkhitektor, pidpryiemets, metsenat [Ivan Levynsky: architect, entrepreneur, philanthropist]. Scien. and lit. editor, author of the concept illustr. material Y. Biriulov. - Lviv: Center of Europe. P. 192. (in Ukrainian)

Pobirchenko. O.M. (2013) Dyzainerska osvita yak zasib harmoniinoho rozvytku osobystosti [Design education as a means of harmonious development of a personality]. Uman: PP Zhovtyi. pp. 136-138. (in Ukrainian)

Synyshyn. L.O. (2014) Formuvannia khudozhno-promyslovoi osvity Halychyny (kinets XIX persha polovyna XX stolittia) [ Formation of art-and-industrial education of Halychyna (the end of XIX - the first half of XX century)]. Pedagogical sciences: theory, history, innovation technologies. № 10 (44). pp. 144-151. (in Ukrainian)

Sokoliuk. L. (1986) Nazustrich istorii mystetskoho zhyttia v Kharkovi. Evoliutsiia Kharkivskoi khudozhnoi shkoly u druhii polovyni XVIII - na pochatku XX stolittia [Towards the history of artistic life in Kharkiv. The evolution Kharkiv art school in the second half of XVIII -the early XX century] dissertation ... of Doctor of art studies Kh. P. 192. (in Ukrainian)

Sokoliuk. L. (1984) Pro deiaki metodolohichni zasady Kharkivskoi khudozhno-promyslovoi shkoly M. D. Raievskoi-Ivanovoi. [About some methodological principles of Kharkiv art-industrial school of M.D. Raievska-Ivanova]. Decorative-applied and monumental art (Intercollegiate collection of scientific papers). M. pp. 2-6. (in Ukrainian)

Turchyn. V. (2004) Osoblyvosti formuvannia dyzainersko-obraznoho myslennia [Features of the formation of design-and-image thinking] synopsis of diss. for obtaining the degree of Doctor of arts. Kh. P. 23. (in Ukrainian)

Tiahur. V.M. (2013) Rozvytok profesiinoi khudozhno-promyslovoi osvity v Nimechchyni (persha polovyna XX st. [ The development of professional art-industrial education in Germany (the first half of the twentieth century] Synopsis of diss. ... for PhD: Kyiv: M.P. Drahomanov Nat. ped. univ. P. 20. (in Ukrainian)

Shabelnyk. S.O. (2012) Vytoky dyzainerskoi osvity [ The origins of design education] (Electronic resource). Regime access: file://C:/Users/WishMasterOk/Downloads/Pipo2012.37.19. pdf(in Ukrainian)

Shmahalo. R.T. (1999) Dosvid strukturuvannia khudozhno-vyrobnychoi osvity Ukrainy [Experience in structuring art-industrial education of Ukraine] educational manual. Lviv: Publishing house" The Syrotynsky brothers and Co" P. 28. (in Ukrainian)

Shmahalo. R.T. Storychni pamiatky lvivskoi khudozhno-promyslovoi shkoly v konteksti rozvytku svitovoi khudozhnoi osvity u druhii polovyni 19-20 st. [The historical landmarks of Lviv artand-industrial school in the context of the development of world art education in the second half of the 19th-20 th centuries]. The bulletin of Lviv national academy of arts. 2001. № 31 . pp. 9-25. (in Ukrainian)

Shmahalo. R.T. (2006) Istorychnyi kurs khudozhno-promyslovoi shkoly u Lvovi [The historical course of art-industrial school in Lviv (1876-1939; 1939-1944) ]. Bulletin 8.The informational issue of 2006-Lviv. pp. 170-175. (in Ukrainian)

Shmahalo. R.T. (2005) Khudozhnia osvita v Ukraini seredyny XIX-seredyny XX stolit: strukturuvannia, metodolohiia, khudozhni pozytsii [Art education in Ukraine in the middle of XIX-the middle of XX centuries:structuring, methodology, artistic positions]. Lviv: Ukrainian Technologies. P. 528. (in Ukrainian)

Entsyklopedychnyi slovnyk [Encyclopedic Dictionary]. Publishing house "Brockhouse F.A. and Efron I.A." St. Petersburg, 1903. T. 74. P. 7. (in Russian). 